\title{
The Cache la Poudre River, Colorado, as a Drinking-Water Source
}

By Jim A. Collins and Lori A. Sprague

$F$ rom October 2002 through Sep-

F tember 2003, the U.S. Geological Survey conducted a study to assess the quality of a subset of the Nation's drinking-water supplies. In the South Platte River Basin of Colorado, the Cache la Poudre River, one of two surface-water sources of drinking water for the city of Fort Collins, Colo., was included in the study. The study focused primarily on the presence or absence of organic chemicals in source water. The 271 compounds studied included dissolved organic carbon, 89 volatile organic compounds, 123 pesticide compounds, and 59 wastewater compounds. Escherichia coli (E. coli) bacteria also was collected. Of the 271 compounds monitored, 257 were not detected. Low concentrations of dissolved organic carbon and E. coli bacteria were detected throughout most of the study period. In addition, 3 volatile organic compounds, 1 pesticide, and 10 wastewater compounds were detected in the Cache la Poudre River. All concentrations detected were below established water-quality standards. Most of the compounds detected appeared to be related to recreation, automobile emissions, or personal and household use of chemicals in the drainage area. Based on the results of this study, the Cache la Poudre River appears to provide a highquality source of drinking water for the city of Fort Collins.

\section{The NAWQA Program}

In 2001, the U.S. Geological Survey's (USGS) National Water-Quality Assessment (NAWQA) Program began its second decade of intensive water-quality assessments (Gilliom and others, 2001). The goals of the NAWQA Program are to assess the quality of surface water, ground water, and aquatic ecosystems throughout the Nation and to understand the primary natural and human factors affecting the quality of these resources. The South Platte River Basin is one of 42 study areas included in the national assessment.

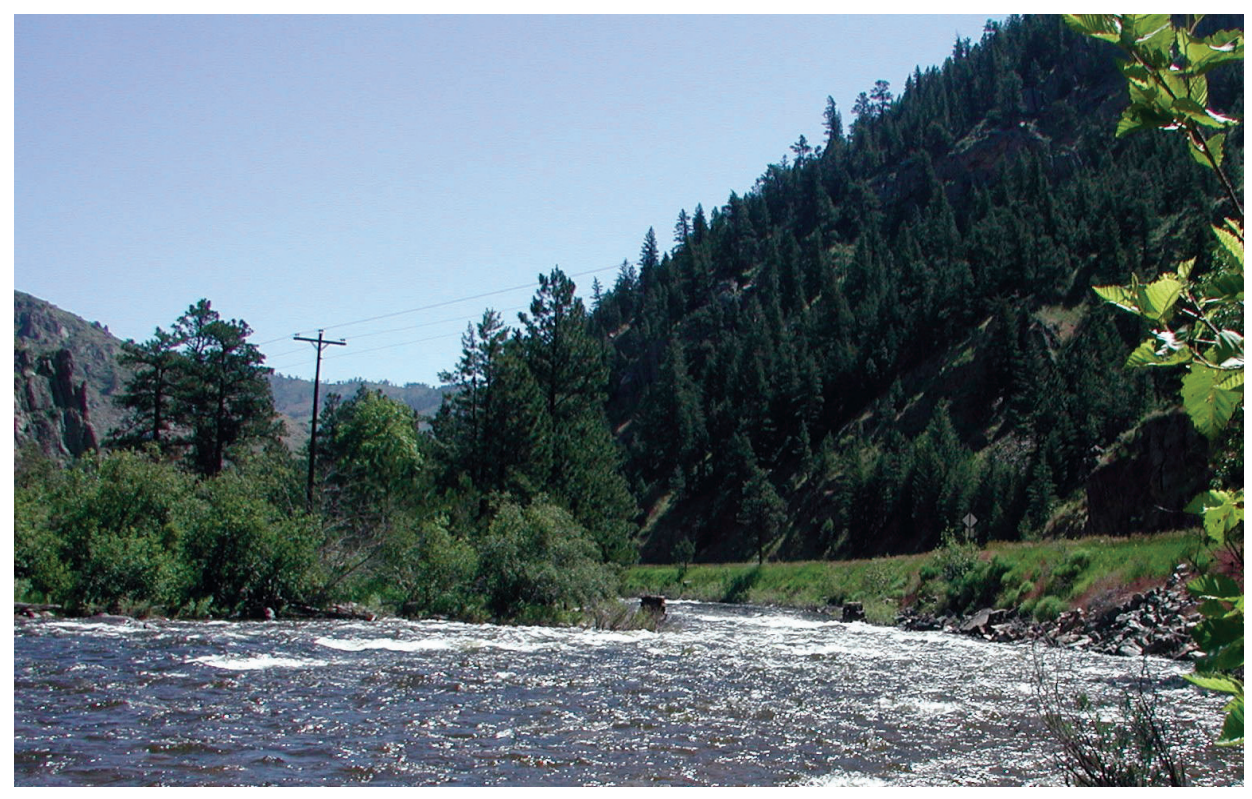

The Cache la Poudre River.

One component of the NAWQA program is to evaluate the quality of a subset of the Nation's publicly supplied drinking water. Surface water (rivers, lakes, and reservoirs) and ground water are used separately or in combination as source water for public-water supply in cities across the Nation. The NAWQA program is evaluating the quality of surface-water and ground-water sources in separate studies. The primary goals of the studies are to (1) evaluate the quality of the source water entering a subset of the Nation's drinking-water treatment facilities, and (2) compare the quality of this source water to the quality of the treated water that is delivered to the public. The study is intended to complement drinking-water monitoring by Federal, State, and local programs, which focus primarily on post-treatment compliance monitoring (Gilliom and others, 2001).

The Source-Water Quality Assessment Study for surface water began in October 2002. First-year activities involved collecting untreated surface-water samples (source water) from nine rivers throughout the United States and analyzing them for a large number of primarily anthropogenic organic chemicals, most of which are not regulated currently (2004) by the U.S. Environmental Protection Agency (USEPA). All sites were at the drinking-water intakes located on major rivers that serve relatively large populations. Lakes and reservoirs are not included in this study. The second year included collecting treated water samples (finished water), along with additional source-water samples to characterize the occurrence and concentration of chemicals in finished water prior to distribution from municipal water-treatment facilities. This report describes the results from the first year of sampling in the South Platte River Basin study area.

\section{The Cache la Poudre River}

In the South Platte River Basin, the Cache la Poudre River was chosen for one of the nine sampling sites because it serves as one of two surface-water sources (together with Horsetooth Reservoir) for the city of Fort Collins, Colo. (fig. 1). The city of Fort Collins water-treatment facility has an annual production of more than 10 billion gallons of finished water that serves a growing Colorado community of more than 125,800 residents (Kevin R. Gertig, Water Production Manager, City of Fort Collins Utilities, written commun., 2005).

The Cache la Poudre River originates in northern Colorado near the 
Continental Divide. The river flows out of Rocky Mountain National Park, through the city of Fort Collins, and eventually into the South Platte River near Greeley, Colo. The sampling site was located in the sparsely populated Cache la Poudre Canyon upstream from the confluence of the North Fork of the Cache la Poudre River with the main stem of the Cache la Poudre River. The drainage area of the study site is approximately 484 square miles, and the land cover is predominately forested (fig. 1). Upstream from the sampling site, a few homes and ranches are near the banks of the river. State Highway 14 parallels the river for approximately 40 miles within the study area. Snowmelt provides most of the flow in the river at the site, with contributions from storm runoff in the summer months and ground-water inflow throughout the year. Streamflows during the study ranged from a low of 20 cubic feet per second $\left(\mathrm{ft}^{3} / \mathrm{s}\right)$ during fall into spring to more than $1,000 \mathrm{ft}^{3} / \mathrm{s}$ during peak summer flows. The natural flows are augmented by transmountain and transbasin diversions that import water from the North Platte and Colorado River drainages with similar forest land use. A large diversion upstream from the site removes water from the stream for downstream agricultural use (Litke and Kimbrough, 1998). The river and surrounding area are very popular for whitewater rafting, canoeing, camping, hiking, and fishing.

\section{Water Sample Collection}

Water samples were collected monthly from the river just upstream from the Fort Collins water-supply intake from October 2002 through September 2003; one additional sample was collected each month from May through September when recreational use of the river was at its peak. Water samples were analyzed for dissolved organic carbon (DOC), 89 volatile organic compounds (VOCs), 123 pesticide compounds, 59 wastewater compounds, and E. coli bacteria. In addition, water temperature, specific conductance, $\mathrm{pH}$, and dissolved oxygen were measured at the time of each sampling. Streamflow also was measured when the samples were collected with exception of during the highest flow during snowmelt, when conditions were not safe for streamflow measurements.

DOC is a general measure of the thousands of compounds found in water that are derived from organic materials; it often is produced within a stream or lake

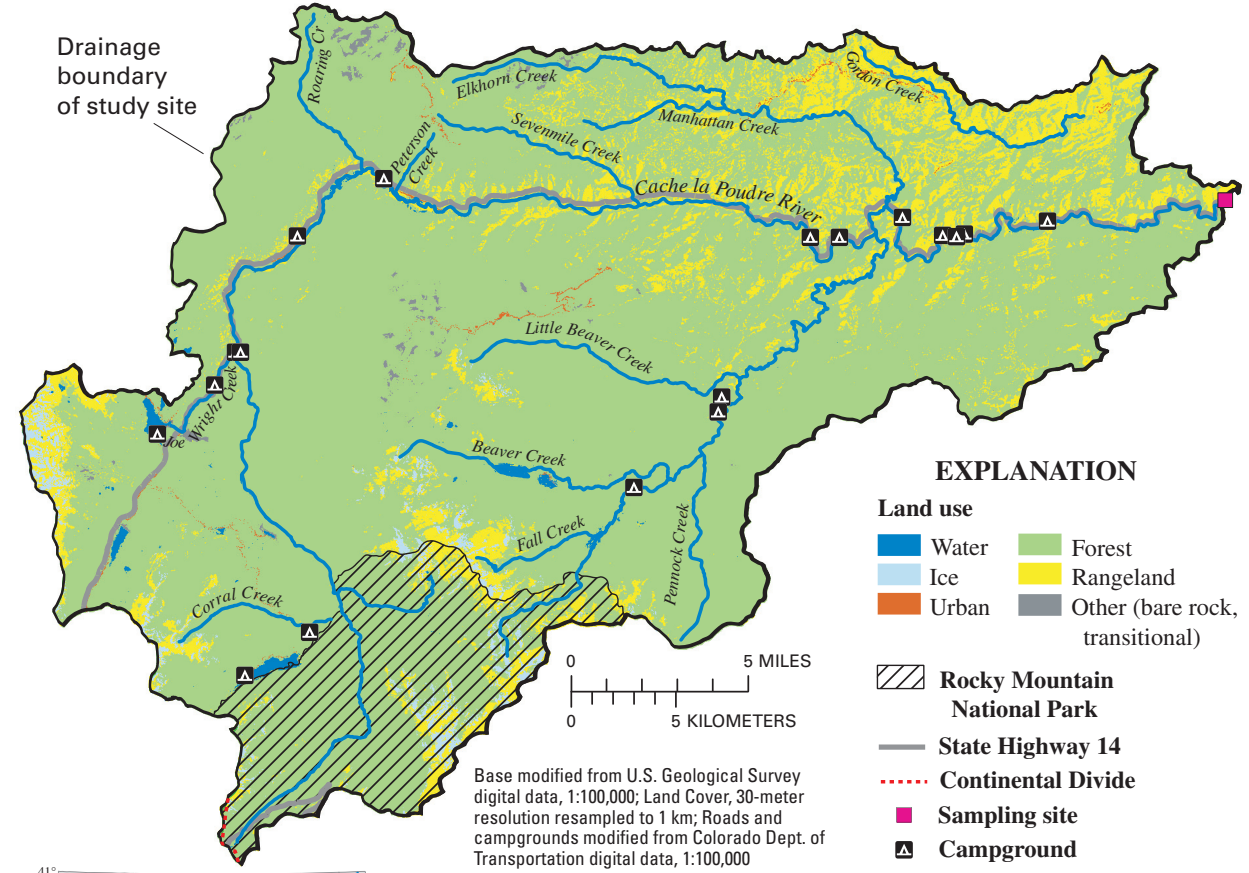

Figure 1. Map of the study area.

Water samples were collected,

from animal feces and decomposition of fish, insects, and plants (Boyer and others, 1997). Increased DOC in drinkingwater supplies has been associated with an increase in the creation of disinfection by-products during chlorination in water-treatment facilities; some of these compounds have been linked with longterm health effects (U.S. Environmental Protection Agency, 1998). VOCs are a group of largely anthropogenic organic chemicals that include solvents, petroleum distillates, some aerosol spray-can propellants, dry-cleaning products, and fumigants. Wastewater compounds are a collection of organic compounds commonly used in and around many households that may be found in septic leachate and wastewater effluent. They include caffeine (found in coffee and many other caffeinated beverages), DEET (found in insect repellent), and camphor (found in topical medications). Pesticides, including herbicides, insecticides, and fungicides, are used to control weeds, insects, and disease-carrying organisms. The $E$. coli bacteria found in streams is derived from a variety of sources, including animal waste or failed septic-system leach fields. Therefore, E. coli can be an indicator of fecal contamination and the possible presence of fecal pathogens (Wilhelm and Malik, 1998). processed, and preserved onsite using standard methods described in the USGS National Field Manual (U.S. Geological Survey, 1997-present) and were analyzed at the USGS National Water-Quality Laboratory in Denver, Colo., using methods described in Brenton and Arnett (1993), Zaugg and others (1995), Connor and others (1997), and Zaugg and others (2002). E. coli samples were analyzed using the modified m-TEC membrane filtration method (U.S. Geological Survey, 1997-present) in the Colorado Water Science Center Laboratory in Denver. Analytical results are available in the USGS National Water Information System at http://water.usgs.gov/nwis.

A quality-assurance sample was collected with more than one-half of the environmental samples. Qualityassurance samples included blanks (used to assess potential sample contamination), replicates (used to assess environmental or laboratory variability), and spikes (used to assess environmental interference with the detection of VOC's, pesticides, and wastewater compounds). Blank concentrations for all compounds were below laboratory reporting limits with the exception of phenol and caffeine. Phenol was detected in multiple blanks, indicating systematic contamina- 
tion during sample collection, processing, or analysis. As a result, phenol detections in the water samples were considered suspect and were removed. Caffeine was detected only in one blank, and the concentration was near the laboratory-reporting limit. As a result, caffeine concentrations were left in the data set, but may be biased slightly high. Concentrations in the replicate samples were consistent with those in the water samples. All spike recoveries were within acceptable ranges.

\section{Detections in the Cache la Poudre River}

DOC concentrations were low throughout the year (fig. 2A). Concentrations were lowest during fall and winter months, with a marked increase during early spring runoff, followed by a decrease as runoff ended in early summer. A likely source of DOC in the river was decomposing plant and organic matter within the soil, which was released into the stream as the water table rose and flow increased during snowmelt (Boyer and others, 1997).

Three of the 89 VOC compoundsacetone, benzene, and toluene-were detected during the study (fig. 2B). Sample detections of acetone occurred in May and September. Low-level detections of benzene and toluene occurred from October through February. Stream
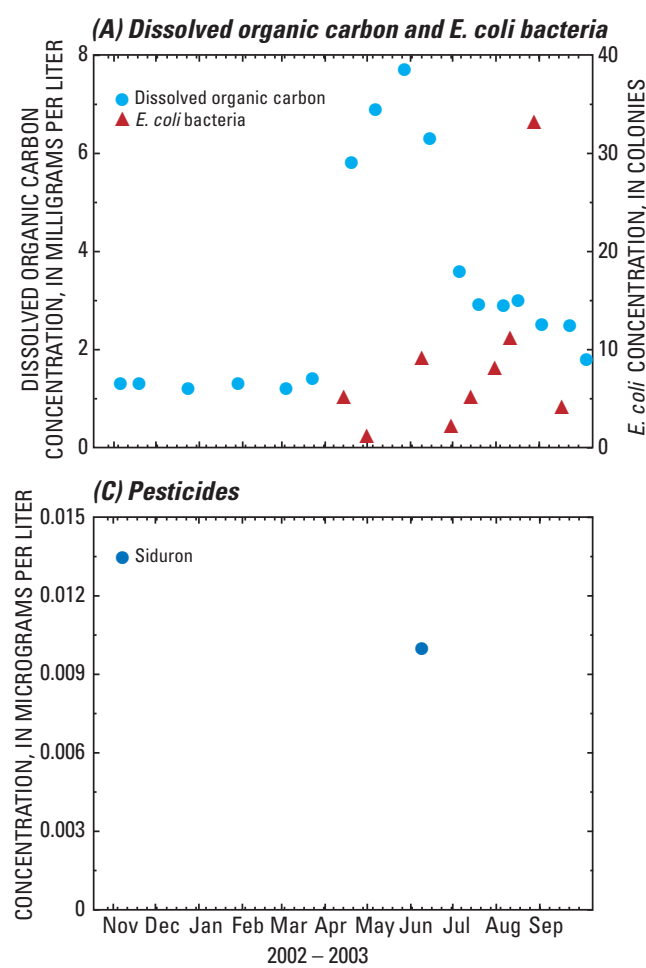

temperatures measured during the study ranged from -0.1 degrees Celsius $\left({ }^{\circ} \mathrm{C}\right)$ in winter to $18^{\circ} \mathrm{C}$ in summer. At water temperatures below $25^{\circ} \mathrm{C}$, the solubility of toluene and benzene, which are components of gasoline and other fuels, generally increases (Shaw, 1989), which may explain why they were detected only in the colder months. The detections of acetone in the spring and summer months may have been related to the increase in automobile traffic and the increase in DOC concentrations; sources of acetone include automobile exhaust and the oxidation of humic carbon substances (Verschueren, 1983).

Siduron, a widely available herbicide used primarily for pre-emergent weed control (Chemical and Pharmaceutical Press, 1993), was the only pesticide of 123 to be detected during the study (fig. 2C). The one detection in June may be attributable to weed control along Highway 14 and on the yards of canyon residents in the spring and summer.

Ten of 59 wastewater compoundsacetophenone, acetyl-hexamethyltetrahydro-naphthalene (AHTN), caffeine, camphor, DEET, diethoxynonylphenol, monoethoxyoctylphenol, para-Cresol, tetrachloroethylene, and triphenyl phosphate-were detected during the study (fig. 2D). Of these compounds, only para-Cresol (two detections) and DEET (seven detections) were detected more than once. With the exception of
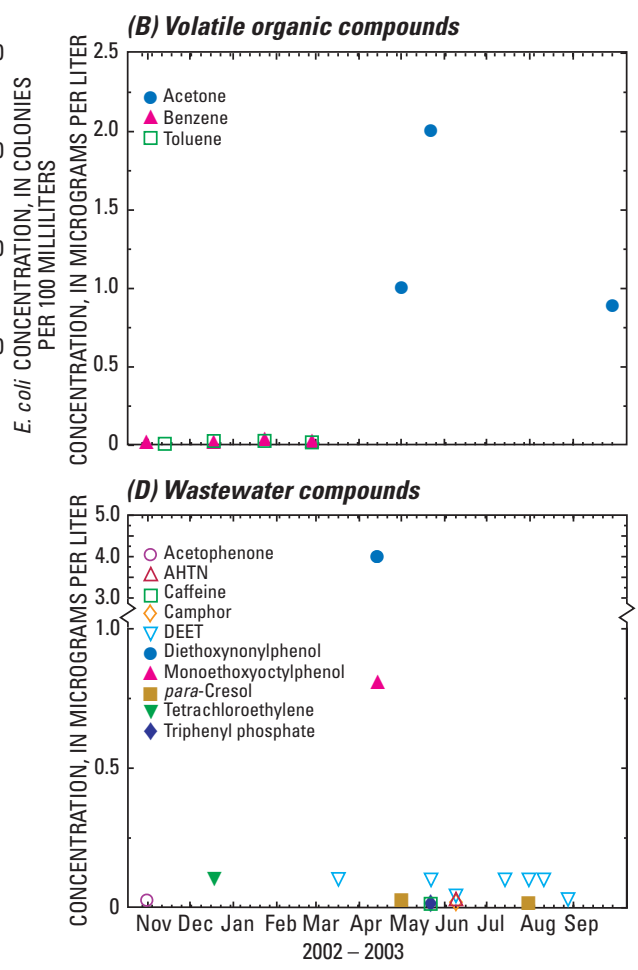

Figure 2. Detections in the Cache la Poudre River. diethoxynonylphenol, all concentrations were less than 1 microgram per liter or one part per billion. The detections of acetophenone, AHTN, diethoxynonylphenol, monoethoxyoctylphenol, para-Cresol, tetrachloroethylene, and triphenyl phosphate likely are related to the seasonal use of various household and personal-care products. DEET, camphor, and caffeine had detections in the spring and summer months when recreational use and contact with the river was at its peak.

Low concentrations of $E$. coli bacteria were detected during the months of April through September (fig. 2A). Bacteria may have been in the river during this time of year due to increased recreation and cattle grazing in the drainage area, combined with warmer streamwater temperatures that can enhance bacterial survival. No bacteria were detected during the late fall and winter when water temperatures were low and use of the river was minimal.

Compared to other streams in urban and agricultural areas of the South Platte River Basin, the number of compounds detected at this site on the Cache la Poudre River was low. Previous studies in the basin have found up to $14 \mathrm{VOC}$ compounds in a single urban stream sample (U.S. Geolgical Survey, 2005, data accessible at http://water.usgs.gov/nwis), 19 pesticide compounds in a single agricultural stream sample (Sprague, 2005), and as many as 37 wastewater compounds in a single urban stream sample (Sprague and Battaglin, 2005).

Potential human-health risks of the compounds measured in this study can be assessed by comparing concentrations in the water samples to standards established by the USEPA and the State of Colorado. Current (2004) standards are listed in table 1 for all of the VOC, wastewater, and pesticide compounds detected in water samples during this study. All concentrations detected in this study were below established standards. These standards, however, do not completely address potential risks. Many of the compounds detected do not have established standards, and there are no standards that account for the potential effects of mixtures of chemicals.

\section{Conclusions}

The Cache la Poudre River was sampled as part of an assessment of 
Table 1. Description of uses or sources, U.S. Environmental Protection Agency (USEPA) maximum contaminant levels, and State of Colorado basic standards for compounds detected during the study.

[MCL, maximum contaminant level; --, no standard currently established; $\mu \mathrm{g} / \mathrm{L}$, micrograms per liter]

\begin{tabular}{|c|c|c|c|c|}
\hline Compound & Common uses or sources & $\begin{array}{c}\text { USEPA } \\
\text { MCL' }^{1} \\
(\mu \mathrm{g} / \mathrm{L})\end{array}$ & $\begin{array}{c}\text { Colorado } \\
\text { standard }^{2} \\
(\mu \mathrm{g} / \mathrm{L})\end{array}$ & $\begin{array}{l}\text { Maximum } \\
\text { study con- } \\
\text { centration } \\
\text { ( } \mu \mathrm{g} / \mathrm{L})\end{array}$ \\
\hline Acetone & Plastic, fibers, drugs, solvents, exhaust by-product & -- & -- & 2.0 \\
\hline Acetophenone & Fragrance in soap, detergent, tobacco & -- & -- & 0.026 \\
\hline Acetyl-hexamethyl-tetrahydro-naphthalene (AHTN) & Fragrance in musk, widespread usage & -- & -- & 0.025 \\
\hline Benzene & Plastics, fibers, lubricants, detergents, pharmaceuticals, fuels & 5 & 1.2 & 0.020 \\
\hline Caffeine & Coffee, soda, tea, and other beverages & -- & -- & 0.016 \\
\hline Camphor & Flavor, odorant, ointments & -- & -- & 0.015 \\
\hline Diethoxynonylphenol & Detergent degradation product & -- & -- & 4.0 \\
\hline Monoethoxyoctylphenol & Detergent degradation product & -- & -- & 0.80 \\
\hline $\mathrm{N}, \mathrm{N}$-diethylmetatoluamide (DEET) & Insect repellant & -- & -- & 0.10 \\
\hline para-Cresol & Wood preservative & -- & -- & 0.030 \\
\hline Siduron & Herbicide & -- & -- & 0.010 \\
\hline Tetrachloroethylene & Solvent, degreaser & 5 & 5 & 0.10 \\
\hline Toluene & Paints, adhesives, lacquers, rubber, paint thinner, fuels & 1,000 & 1,000 & 0.030 \\
\hline Triphenyl phosphate & Plasticizer, resins, finishes, waxes, and roofing paper & -- & -- & 0.014 \\
\hline
\end{tabular}

the quality of a subset of the Nation's publicly supplied drinking water. The number of detections and concentrations of the largely unregulated chemicals sampled were low in the Cache la Poudre River compared to the other eight rivers sampled as part of this source-water quality assessment (Greg Delzer, U.S. Geological Survey, written commun., 2003). Because of the small number of detected compounds and the low concentrations measured in the Cache la Poudre River, major differences between the source water in the river and the treated water delivered to Fort Collins residents were not expected. Therefore, this site was not included during the second year of the source-water quality assessment study. The city of Fort Collins blends water from both the Cache la Poudre River and Horsetooth Reservoir throughout the year to supply water to residents, and further study of both water sources would be needed to assess the overall quality of source water for the city. Based on the results of this study, the Cache la Poudre River appears to provide high-quality source water for the city of Fort Collins.

\section{References Cited}

Boyer, E.W., Hornberger, G.M., Bencala, K.E., and McKnight, D.M., 1997, Response characteristics of DOC flushing in an alpine catchment: Hydrologic Processes, v. 11, p. $1,635-1,647$.

Brenton, R.W., and Arnett, T.L., 1993, Methods of analysis by the U.S. Geological Survey National Water-Quality LaboratoryDetermination of dissolved organic carbon by UV-promoted persulfate oxidation and infrared spectrometry: U.S. Geological Survey Open-File Report 92-480, 12 p.
Chemical and Pharmaceutical Press, 1993, Crop protection chemicals reference: New York, Wiley and Boris Chemical and Pharmaceutical Publishing Corporation, 9th ed., 1,812 p. and supplement.

Colorado Department of Public Health and Environment Water-Quality Control Commission, 2001, The basic standards and methodologies for surface water: Regulation no. $31,175 \mathrm{p}$.

Connor, B.F., Rose, D.L., Noriega, M.C., Murtagh, Lucinda, and Abney, S.R., 1997, Methods of analysis by the U.S. Geological Survey National Water-Quality Laboratory-Determination of 86 volatile organic compounds in water by gas chromatography/mass spectrometry, including detections less than reporting limits: U.S. Geological Survey Open-File Report 97-829, 78 p.

Gilliom, R.J., Hamilton, P.A., and Miller, T.M., 2001, The National Water-Quality Assessment Program-Entering a new decade of investigations: U.S. Geological Survey Fact Sheet 071-01, 6 p.

Litke, D.W. and Kimbrough, R.A., 1998, Water-quality assessment of the South Platte River Basin, Colorado, Nebraska, and Wyoming-Environmental setting and water quality of fixed sites, 1993-1995: U.S. Geological Survey Water-Resources Investigations Report 97-422, 61 p.

Shaw, D.G., 1989, Hydrocarbon with water and seawater, Part I-Hydrocarbons C5 to C7: International Union of Pure and Applied Chemistry, v. 37, variously paged.

Sprague, L.A., 2005, Drought effects on water quality in the South Platte River Basin, Colorado: Journal of the American Water Resources Association, v. 41, no. 1, p. 11-24.

Sprague, L.A., and Battaglin, W.A., 2005, Wastewater chemicals in Colorado's streams and ground water: U.S. Geological Survey Fact Sheet 2004-3127, 4 p.
U.S. Environmental Protection Agency, 2003, National primary drinking water standards: Washington, D.C., EPA Report 816-F-03-016.

U.S. Environmental Protection Agency, 1998, National primary drinking water regulations - disinfectants and disinfection byproducts: Federal Register, v. 63, no. 241, p. $69,389-69,476$.

U.S. Geological Survey, variously dated, National field manual for the collection of water-quality data: U.S. Geological Survey Techniques of Water-Resources Investigations, book 9, chaps. A1-A9, accessed September 14, 2004, at http://pubs.water. usgs.gov/twri9A, variously paged.

Verschueren, Karel, 1983, Handbook of environmental data on organic chemicals: New York, Van Nostrand Rienhold, 1310 p.

Wilhelm, L.J., and Malik, T.L., 1998, Fecalindicator bacteria in surface waters of Santee River Basin and coastal drainages, North and South Carolina, 1995-98: U.S. Geological Survey Fact Sheet FS-085-98, $6 \mathrm{p}$.

Zaugg, S.D., Smith, S.G., Schroeder, M.P., Barber, L.B., and Burkhardt, M.R., 2002, Methods of analysis by the U.S. Geological Survey National Water-Quality Laboratory-Determination of wastewater compounds by polystyrene-divinylbenzene solid-phase extraction and capillary-column gas chromatography/mass spectrometry: U.S. Geological Survey Water-Resources Investigations Report 01-4186, 37 p.

Zaugg, S.D., Sandstrom, M.W., Smith, S.G., and Fehlberg, K.M., 1995, Methods of analysis by the U.S. Geological Survey National Water-Quality Laboratory-Determination of pesticides in water by $\mathrm{C}-18$ solid-phase extraction and capillary-column gas chromatography/mass spectrometry with selected-ion monitoring: U.S. Geological Survey Open-File Report 95-181, 49 p. 